\title{
Global Oil Price and Its Economic Impact in Bangladesh
}

\author{
Shirin Sultana, Md. Nasim Uddin* \\ Senior Lecturer, School of Business, Asian University of Bangladesh, Uttara Model Town, Dhaka-1230, BANGLADESH \\ *E-mail for correspondence: $\underline{\text { h1n1flue09@gmail.com }}$
}

https://doi.org/10.18034/abr.v8i1.148

\begin{abstract}
This paper highlighted the plummeting price of oil that is at present the most sensational energy story in the world. This research work outlined the main reasons for the current situation is the low demand for oil as well as concerned companies found it more profitable to extract oil by unconventional methods. In Bangladesh, no changes have been made in the oil price. By figure, at present (June 2017) BPC (Bangladesh Petroleum Corporation) is making profit of Tk 13.77 per liter of Kerosene, of Tk 14.68 per liter of Diesel, of Tk 19.57 per liter of Furnace oil and of Tk 18.75 per liter of jet fuel oil where the very latest world crude oil price come down $\$ 35.62$. The present study is done to make the overview of the world oil prices and Bangladesh as well using purely secondary data collected mostly from newspaper reports, websites, magazines, journals, periodic, reviews and various published data. This study also investigates the impact of the sharp fall oil price to the economy of Bangladesh. In the study, there is seen negatively correlation with the oil price of the world and that of Bangladesh. This paper will be useful to the all stakeholders even policy makers to take proper initiatives for the adjustment of the plummeting oil price of the world. This present study may disseminate that the BPC, as the government-sponsored firm, cannot make the maximum profit as like the Monopoly Company in Bangladesh, so, the retail consumer may give the benefits of the adjustment with the sharp oil price fall in the world.
\end{abstract}

Key words: BPC, GDP, CPI, Petroleum, Plummeting, Secondary Data

\section{INTRODUCTION}

In fact, Bangladesh has been experiencing a vigorous rate of GDP (Gross Domestic Product) growth for the duration of the sixth plan period, and at the similar time, it has effectively attainment a noteworthy decline in the rate of inflation. The result shows becoming the middle lower income country of the world. In the figure, the GDP of Bangladesh in the fiscal year of 2015, it is forecasted at $6.4 \%$ that is $4.92 \%$ more than the year of 2014 .

Besides, the inflation rate in the year 2017 also forecasted at $6.5 \%$ that will be $12.16 \%$ less than the year of 2014 . In spite of continuous pervasiveness of an ambiance of "democratic discomfort," Bangladesh's financial year 2014-15 (FY2015) is final with some macroeconomic reward as well as minor inflation, decreasing interest rate, steady exchange rate, controllable financial insufficiency, positive equilibrium of payment and enlarged foreign exchange reserves. In fact, the current account of the balance of payments is expected to show a higher surplus at $1.5 \%$ of GDP in the fiscal year 2015 that is up from $0.9 \%$ in 2014 . Export earnings enlarged at a superior rate than imports, and export-GDP ratio greater than before in the 2014 whereas import-GDP ratio decreased. Notwithstanding political disorder, structural obstacle, and worldwide unpredictability, the Bangladeshi economy is keeping macroeconomic steadiness and poignant onward. The worldwide improvement, well-built home demand enlargement, and unremitting macro permanence divine healthy for Bangladesh's GDP intensification and scarcity diminution. Though domestic production, particularly that of rice influences output and price stability, inflation in Bangladesh is also largely determined by international prices since the country has to depend on some essential commodities including petroleum products. In Bangladesh, $45 \%$ of the fuel uses in the transport sector, $25 \%$ in the power sector, $19 \%$ in the agriculture sector, $4 \%$ in the industries and $7 \%$ in the household sector. Therefore minor prices of food and oil at the worldwide marketplace at current have been a wellknown issue for the decrease inflation velocity. The squat stage of worldwide goods prices together with that of oil has also given some reprieve regarding funds required to meet up subsidy demands. Many infrastructures, vehicles, manufacturing industries, house hold works are managed 
using oil as the key fuel in Bangladesh. Bangladesh is a net oil importer. Bangladesh is completely reliant on imports for meeting up its demand for petroleum goods. According to government data, the country imported 53.51 lakh tons of petroleum products worth Tk 36,587 crore in fiscal 201314 Of the money, 65 percent expenses on diesel import. According to the finance ministry of Bangladesh, the government has to support financially fuel imports to reduce customers in opposition to price shocks. It used up Tk 7,350 crore on fuel subsidies in 2013-14, downhill from Tk 13,558 crore in the preceding year.

A well-built justification for subsidizing power is to hold up access to power for the deprived. While there's some extent of truth to the current argument, energy subsidies usually profit wealthier segments of society disproportionately, as long as they use additional energy. This is often true in East Pakistan, wherever the poor square measure largely addicted to ancient biomass and has very little access to electricity and alternative public utilities.

Energy subsidies conjointly divert public funds from social programs and welfare schemes which will be of bigger profit to the poor. Even so, a rise in energy prices will have a disproportionate impact on poorer voters if adequate social safety nets don't seem to be in situ. Governments conjointly give energy subsidies to support vital components of the economy. As an example, energy subsidies play a crucial role in Bangladesh's agriculture sector that employs nearly half the country's labor. Bangladesh's agricultural sector depends heavily on energy-intensive irrigation, particularly throughout the time of year.

Nearly eighty seven percent of the irrigation instrumentality is run on diesel, accounting for nearly seventy one percent of the world beneath mechanized irrigation. Naturally, shortages or worth hikes in power or fuel result in higher production prices and, afterwards to higher market costs for agricultural product, significantly rice, the staple food. World oil costs have gone record low throughout the last many months. Lower oil worth within the world market could be a blessing for East Pakistan because it will save exchange that successively may be used for alternative imports.

A Wall Street Journal report on August 23, 2015 said the price of crude oil dropped to $\$ 40$ a barrel, lowest since March 2009. The oil prices also fell in Europe that is on August 2015, a barrel of oil was sold at $\$ 45.46$. West Texas Intermediate prices for October, 2015 delivery dropped to $\$ 39.86$ per barrel on the New York Mercantile Exchange. In this present paper the researcher has presented the review regarding the plummeting oil price and its impact on the economy of Bangladesh using the secondary data.

\section{LITERATURES REVIEW}

Review of literature is an integral part of conducting a research. Review of past literature helps conceptualization, formulation and choice of tools of analysis. It also helps in arriving at meaningful conclusions. With this view a brief review of past studies and concepts relevant to the present study are highlighted in below.

Rahman, M. (2015) the low level of worldwide trade goods costs together with that of oil has conjointly provided some respite in terms of resources required to satisfy grant demands. Developing countries of Asia managed to accelerate their growth rates, with Asian nation and also the association countries being within the lead (ADB, 2015). On the opposite hand, the most important economies within the international economic frontier (i.e. the use of America, countries within the Common Market, associate degreed Japan) are growing at an uneven pace, limiting the world growth prospects to solely three per cent in 2015, as projected by the planet Bank (2015).

Tabassum, T., (2015) opined that the plummeting price of oil is, at present, the most sensational energy story in the world. For much of the past decade, because of soaring oil consumption in countries like China and conflicts in key oil nations like Iraq, oil production could hardly cope with the demand-thus causing prices to spike. But many of these dynamics were rapidly shifting, till prices dropped steeply in September 2014 while wreaking havoc on oil-producing countries economies, this is proving to be a boon for oil importing countries.

Rahman, S. (2014) mentioned in his research paper that the economic system is getting the advantages of the falling expenditures of oil as the government's spending on subsidy will go down extensively and stability of repayments will be healthier. If people get the fee benefits, both the value of doing business and inflation will fall.

Haque, A. K. E. (2007) told that a total of five different world oil price scenarios have been used to simulate impact of world oil price changes. The base scenario (BASE) is set to understand 'what if' the world oil price remains where it was in 2002 prior to price rise. This can be compared with reduced oil demand (ROD) scenario in which price of oil was set to rise until it triggers a change in the demand for oil and people switch to substitute sources of energy.

Taslim M. A. (2014) opined that usually, lower oil prices helps reduce the cost of living by lowering transport costs and bringing down inflation. Lower oil prices also pass through directly into lower fuel costs and retail electricity prices.

M Tamim, M. (2015) also mentioned that Bangladesh has always subsidized diesel and Octane/petrol has been used for cross subsidy. Agriculture uses only 30\% diesel and the subsidy has continued in its name. Ideally all prices should be market based but Government cannot maintain a fuel price based tariff formula in the transport sector. Because of that consumers never get the benefit when the price drops. Furnace oil is being used to produce electricity only and that can be easily controlled as the entire matter is with the government. 


\section{Objectives of the Study}

The major objective of the study is to investigate the existing practices of oil price trends and its impact on the economy of Bangladesh. The specific objectives are:

- To overview the existing oil import and its value in Bangladesh.

- To show the comparative historical oil price in the World and Bangladesh.

- To measure the financial trends of the historical oil price movement in Bangladesh.

- To show the relationship among the oil price elasticity and GDP \& CPI in South Asia.

- To examine the economic impacts of oil price movement in Bangladesh.

\section{Rationale of the Study}

Bangladesh oil and gas market is experiencing major changes in new project development, consumption patterns and market scenario amidst rapidly shifting global dynamics. This research work provides analysis of historical oil price of Bangladesh \& the World and its key impacts associated challenges facing Bangladesh markets. The price of Brent crude oil, the major trading classification of sweet light crude oil that serves as a major benchmark price for purchase of oil worldwide, slumped below per barrel, its lowest level since 2010. The present study is done to analyze that the lower oil prices if sustain should have a positive effect on domestic growth. In theory, the fall in oil prices could lead to higher purchasing power and consumer spending and hence add to real GDP. Moreover, this study is also done to know the impact of lower oil prices that is broadly positive to oil importers like Bangladesh.

\section{LIMITATIONS OF THE STUDY}

This research has some limitations and future work can be done. Due to lack of time of the researcher, the study has been done using purely secondary data and no primary data is used. This research was conducted mostly in a quantitative way. It will be better to continue some qualitative research and make comparison between qualitative and quantitative results to know the accurate rationality of the selected topic and fields. Considering of all the limitations of this study, the researcher thinks that in future it will be convenient for the researchers to deal with any gap derived from this study.

\section{Methods AND MATERIALS}

The study is expressive as well as investigative in nature and based on merely secondary data collected from relevant research reports \& publications, annual reports, periodic, journals, reviews, newspaper reports, magazines, website and books. Although a mild volume of facts are collected from the important sources by using interviews of the some filling stations and the strength experts. The collected data regarding the oil price has been analyzed using MS-Office and simple statistical techniques like table, graphs, percentage and growth for drawing inferences.

\section{ANALYSIS AND FINDINGS}

Oil prices are free-fall since last few years. The price of West Texas Intermediate crude oil June 2014 was around at \$ 108 a barrel. This price has sharply fallen by around $65 \%$ and stood at \$ 38 a barrel in August 24, 2015. Now the price stood at \$ 39.68 a barrel in December 15, 2017. The following table 1 shows the historical 10 years average oil price in the world.

Table: 1: World Average Crude Oil Price

\begin{tabular}{|c|c|c|c|}
\hline \multirow{2}{*}{ Year } & \multicolumn{3}{|c|}{ As on December } \\
\cline { 2 - 4 } & Dollar in Per Barrel & BDT in Per Barrel & $\%$ Change \\
\hline 2007 & 59.4 & 4752 & - \\
\hline 2008 & 62.0 & 4960 & 4.37 \\
\hline 2009 & 91.7 & 7336 & 47.90 \\
\hline 2010 & 41.0 & 3280 & -53.19 \\
\hline 2011 & 74.30 & 5944 & 81.22 \\
\hline 2012 & 89.04 & 7123.2 & 19.84 \\
\hline 2013 & 98.57 & 7885.6 & 10.70 \\
\hline 2014 & 88.25 & 7060 & -11.47 \\
\hline 2015 & 97.63 & 7810.4 & 10.63 \\
\hline 2016 & 59.29 & 4743.2 & -40.18 \\
\hline 2017 & 35.62 & 2849.6 & -40.92 \\
\hline Mean & 72.44 & 5795.2 & 2.98 \\
\hline
\end{tabular}

Source: NASDAQ

The above table 1 shows the historic world crude oil price per barrel and its change in percentage where the base year shows the price of $\$ 59.4$ followed by upwards trends $\$ 62$ and 91.7 in the years of 2008 and 2009 respectively. But in the year of 2010 the massive downwards change of oil price has been made as a result the price stood at $\$ 41.0$ with the change of $-53.19 \%$.

Graph 1: World Average Crude Oil Price

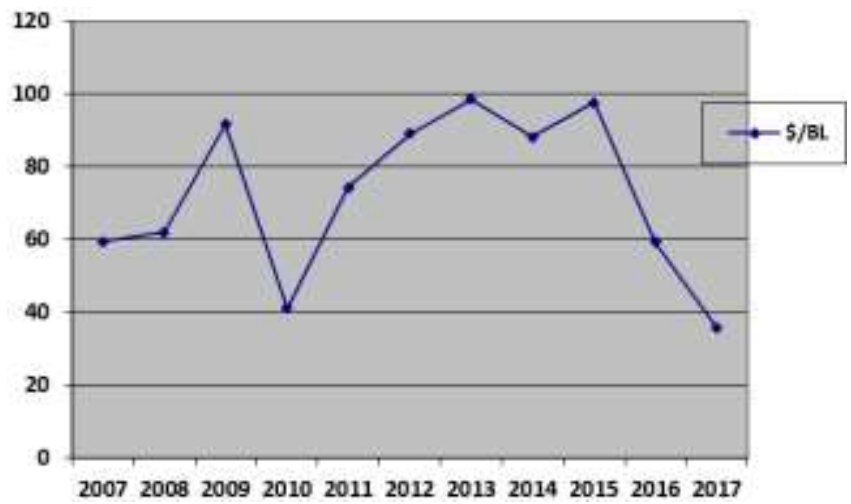

But again from 2011 the price had the upwards trend since the year of 2015. Then the price frequently change, particularly the price of the oil can be showed by month of the recent time to know its frequent change such as January 2016 \$ 94.62, April 2016 \$ 102.07, June 2016 \$ 105.79, July 2016 \$ 103.59, August 2016 \$ 96.54, September 2016 \$ 93.21, October 2016 \$84.40, November 2016 \$75.79, December 2016 \$ 59.29, January 2017 \$ 47.22, February 2017 \$ 50.58, March 
2017 \$ 47.82, June 2017 \$ 54.5. the average price from 2007 to 2017 becomes $\$ 72.44$ with the percentage change 2.98. The above graph can also present the historical oil price and its changing dimension from the year of 2007 to 2017 at a glance.

Table 2: Quantity of Imported Oil and its Price

\begin{tabular}{|c|c|c|c|c|c|c|c|c|c|c|}
\hline \multirow[b]{2}{*}{ Year } & \multicolumn{2}{|c|}{ Crude oil } & \multicolumn{2}{|c|}{$\begin{array}{c}\text { Refined products (HSD, } \\
\text { SKO, Jet \& Mogas) }\end{array}$} & \multicolumn{2}{|c|}{ HSFO } & \multicolumn{2}{|c|}{ Total } & \multicolumn{2}{|c|}{ Statistics } \\
\hline & $\begin{array}{l}\text { Qnty. } \\
\text { (Mt) }\end{array}$ & \begin{tabular}{|c|} 
Price \\
$(\mathrm{Cr} . \mathrm{Tk})$
\end{tabular} & $\begin{array}{l}\text { Qnty. } \\
\text { (Mt) }\end{array}$ & $\begin{array}{l}\text { Price } \\
\text { (Cr. Tk) }\end{array}$ & $\begin{array}{l}\text { Qnty. } \\
\text { (Mt.) }\end{array}$ & $\begin{array}{c}\text { Price } \\
\text { (Cr.Tk) }\end{array}$ & $\begin{array}{l}\text { Qnty } \\
\text { (Mt.) }\end{array}$ & $\begin{array}{c}\text { Price } \\
(\mathrm{Cr} . \mathrm{Tk})\end{array}$ & $\begin{array}{l}\text { Mean } \\
\text { Qnty }\end{array}$ & $\begin{array}{l}\text { Mean } \\
\text { Price }\end{array}$ \\
\hline $2007-08$ & \begin{tabular}{|l|}
1253285 \\
\end{tabular} & 3750.69 & 2380533 & 9382.77 & 0 & 0 & 3633818 & 13133.46 & 1211273 & 4377.82 \\
\hline 2008-09 & \begin{tabular}{|l|}
1211037 \\
\end{tabular} & 3985.02 & 2536535 & 10446.2 & 0 & 0 & \begin{tabular}{|l|}
3747572 \\
\end{tabular} & 14431.22 & 1249191 & 4810.407 \\
\hline 2009-10 & 1040084 & 5093.69 & 2273263 & 14343.04 & 0 & 0 & 3313347 & 19436.73 & 1104449 & 6478.91 \\
\hline $2010-11$ & 860877 & 3431.4 & 2507819 & 10945.24 & 29920 & 60.38 & 3398616 & 14437.02 & 1132872 & 4812.34 \\
\hline 2011-12 & 1136567 & 4701.54 & 2634212 & 12028.18 & 0 & 0 & 3770779 & 16729.72 & 1256926 & 5576.573 \\
\hline 2012-13 & 1409302 & 7037.00 & 3259344 & 20280.52 & 230431 & 1123.17 & \begin{tabular}{|l|}
4899077 \\
\end{tabular} & 28440.69 & 1633026 & 9480.23 \\
\hline 2013-14 & \begin{tabular}{|l|}
1083467 \\
\end{tabular} & 7053.51 & 3409934 & 27111.24 & 680982 & 3819.07 & 5174383 & 37983.82 & 1724794 & 12661.27 \\
\hline 2014-15 & 1292102 & 8536.70 & 2827160.29 & 219493.10 & 803603.36 & 4367.26 & \begin{tabular}{|l|}
4922866 \\
\end{tabular} & 232397.1 & 1640955 & 77465.69 \\
\hline 2015-16 & \begin{tabular}{|l|}
1176693 \\
\end{tabular} & 7957.29 & 3158343.00 & 23485.56 & 1016101 & 5144.68 & \begin{tabular}{|l|}
5351137 \\
\end{tabular} & 36587.53 & 1783712 & 12195.84 \\
\hline 2016-17 & \begin{tabular}{|l|}
1303194 \\
\end{tabular} & 5739.35 & 3403889.76 & 18569.62 & 691704.62 & 2714.30 & \begin{tabular}{|l|}
5398789 \\
\end{tabular} & 27023.27 & 1799596 & 9007.757 \\
\hline Total & 11766609 & 57286.19 & 28391033 & 366085.5 & 3452742 & 17228.86 & \begin{tabular}{|l|}
43610384 \\
\end{tabular} & 440600.5 & & \\
\hline Mean & 1176661 & \begin{tabular}{|l|}
5728.619 \\
\end{tabular} & 2839103 & 36608.55 & 345274.2 & 1722.886 & \begin{tabular}{|l|}
4361038 \\
\end{tabular} & 44060.05 & & \\
\hline S.D. & 3060312 & \begin{tabular}{|l|}
14974.75 \\
\end{tabular} & 7386658 & 111597.6 & 969251.9 & 4856.80 & 11356762 & 129440.6 & & \\
\hline
\end{tabular}

Note: SKO- Superior Kerosene Oil, HSFO- High Sulphur Furnace Oil, MOGAS- Motor Gasoline

Source: Bangladesh Petroleum Corporation

The above table shows the quantity of imported oil in metric ton and its value in BDT (Crore). The table shows 10 years quantity and value of Crude Oil, Refined products, High Sulphur Furnace Oil in Bangladesh where total crude oil 11,766609 Mt of BDT (Crore) 57,286.19, refined product 28,391033 Mt of BDT (Crore) 36,6085.5 and HSFO 43, 610384
Mt of BDT (Crore) 44, 0600.5 imported as the net import country of the world. By year wise the highest average value of all products is BDT (Crore) 17, 99, 596 in 2016-2017 while the lowest BDT (Crore) 1,21,1273 in the year of 20072008.Moreover, the total oil imported from 2005-06 to 20142015 of 4, 36, 10,384 Mt of BDT (Crore) 44, 0600.

Table 3: Average Unit Price of Petroleum Products Import

\begin{tabular}{|c|c|c|c|c|c|c|c|c|c|}
\hline \multirow{2}{*}{ Ciscal Year } & \multicolumn{3}{|c|}{ Crude Oil } & \multicolumn{3}{c|}{ Refined Oil } & \multicolumn{3}{c|}{ Lube Oil } \\
\cline { 2 - 11 } & US \$/bbl & BDT/bbl & $\%$ Change & US \$/bbl & BDT/bbl & $\%$ Change & US \$/bbl & BDT/bbl & $\%$ Change \\
\hline $2007-08$ & 59.04 & 4723.2 & - & 75.92 & 6073.6 & - & 140.43 & 11234.4 & - \\
\hline $2008-09$ & 63.59 & 5087.2 & 7.71 & 78.31 & 6264.8 & 3.15 & 119.03 & 9522.4 & -15.24 \\
\hline $2009-10$ & 95.70 & 7656 & 50.49 & 119.07 & 9525.6 & 52.05 & 122.16 & 9772.8 & 2.63 \\
\hline $2010-11$ & 76.87 & 6149.6 & -20.68 & 83.04 & 6643.2 & -31.26 & 99.73 & 7978.4 & -19.37 \\
\hline $2011-12$ & 75.66 & 6052.8 & -2.57 & 86.17 & 6893.6 & 3.77 & 142.38 & 11390.4 & 42.77 \\
\hline $2012-13$ & 93.13 & 7450.4 & 23.09 & 113.69 & 9095.2 & 31.94 & 179.85 & 14388 & 26.32 \\
\hline $2013-14$ & 112.95 & 9036 & 21.28 & 128.30 & 10264 & 12.85 & 178.63 & 14290.4 & -0.67 \\
\hline $2014-15$ & 109.22 & 8737.6 & -4.30 & 127.70 & 10216 & -0.47 & 142.04 & 11363.2 & -20.40 \\
\hline $2015-16$ & 109.60 & 8768 & 0.35 & 125.27 & 10021.6 & -2.81 & - & - & - \\
\hline $2016-17$ & 75.23 & 6018.4 & -32.35 & 90.16 & 7212.8 & -28.03 & - & - & - \\
\hline Mean & 87.10 & 6968 & 15.78 & 102.76 & 8220.8 & 13.98 & 140.53 & 11242.4 & - \\
\hline S.D. & 19.69 & 1575.2 & & 21.88 & 1750.4 & - & 27.95 & 2275 & \\
\hline
\end{tabular}

Source: Bangladesh Petroleum Corporation

The table 3 shows the per barrel oil price imported by Bangladesh from the year of 2007-08 to 2016-17 where the products are crude oil, refined oil and lube oil. The mean prices of the oil are $\$ 87.10$ of crude oil, $\$ 102.76$ of refined product and $\$ 140.53$ of lube oil. The deviations of the mentioned oil price over the periods are seen \$ 19.69, \$ 21.88 and $\$ 27.95$ respectively. The percentage changes over the year are also mentioned here.
Table 4 shows the unit retail selling price of the petroleum products in Bangladesh with the percentage changes during the period of 2011 to 2017. It is seen that the price of the petroleum product of the mentioned periods are always upwards trends. Though, from the year of 2016 to the present the piece is remained unchanged because of the sharp fall of the world oil price. The percentage of the change from year to year is also significant. 
Table 4: Selling Price of Petroleum Product in Bangladesh (BDT/Liter)

\begin{tabular}{|c|c|c|c|c|c|c|c|}
\hline $\begin{array}{c}\text { Petroleum } \\
\text { products }\end{array}$ & 2011 & 2012 & 2013 & 2014 & 2015 & 2016 & 2017 \\
\hline Kerosene & 32.37 & 40.00 & 56.00 & 61 & 68 & 68 & 68 \\
\hline$\%$ Change & - & $23.57 \%$ & $40 \%$ & $8.93 \%$ & $11.47 \%$ & $0 \%$ & $0 \%$ \\
\hline Diesel & 44.25 & 46.18 & 56.00 & 61 & 68 & 68 & 68 \\
\hline$\%$ Change & - & $4.36 \%$ & $21.26 \%$ & $8.93 \%$ & $11.47 \%$ & $0 \%$ & $0 \%$ \\
\hline Petrol & 74.70 & 80.50 & 86 & 91 & 96 & 96 & 96 \\
\hline$\%$ Change & - & $7.76 \%$ & $6.83 \%$ & $5.81 \%$ & $5.49 \%$ & $0 \%$ & $0 \%$ \\
\hline Octane & 77.70 & 84.50 & 89 & 94 & 99 & 99 & 99 \\
\hline$\%$ Change & - & $8.75 \%$ & $5.33 \%$ & $5.62 \%$ & $5.32 \%$ & $0 \%$ & $0 \%$ \\
\hline Furnace oil 14.00 & 20.00 & 55.00 & 56.00 & 60 & 60 & 60 \\
\hline$\%$ Change & - & $42.86 \%$ & $175 \%$ & $1.82 \%$ & $7.14 \%$ & $0 \%$ & $0 \%$ \\
\hline
\end{tabular}

Source: Bangladesh Petroleum Corporation

The table 5 shows the Pearson correlation matrix among the unit prices of world average crude oil, imported crude oil and refined oil by Bangladesh. Here viewed all negative correlations between the unit promoting fee of all petroleum merchandise of Bangladesh and that of World common crude oil and imported oil price by means of Bangladesh. Particularly the price of petrol and octane are showing high negative correlations that means the price of the world oil is in downwards trend but the price in Bangladesh is upwards trends.

Table 5: Pearson Correlation Matrix

\begin{tabular}{|c|c|c|c|c|c|}
\hline & \multicolumn{2}{|c|}{ Unit PriceUnit Price } & \multicolumn{2}{|c|}{ Unit PriceUnit Pric } & Jnit Pric \\
\hline & Kerosene & Diesel & Petrol & Octane & Furnace \\
\hline $\begin{array}{l}\text { World Average } \\
\text { Crude oil Price }\end{array}$ & -0.791 & -0.672 & -0.962 & -0.945 & -0.517 \\
\hline $\begin{array}{l}\text { Unit Price Crude } \\
\text { Oil Imported }\end{array}$ & -0.593 & -0.703 & -0.615 & -0.495 & -0.532 \\
\hline $\begin{array}{l}\text { Unit Price Refined } \\
\text { Oil Imported }\end{array}$ & -0.811 & -0.841 & -0.723 & -0.586 & -0.750 \\
\hline
\end{tabular}

The table 6 shows the comparative oil price as on December 2015 in both UD and BDT where World, India and Bangladesh are taken as the sample. In the table we can see the difference of the oil price of two most used petroleum products by the general public Diesel and Petrol. In case of diesel the selling price is BDT 4.80 more than world price and BDT 8 more than India.

Table 6: Present Comparative Oil Price

\begin{tabular}{|c|c|c|c|}
\hline \multirow{2}{*}{$\begin{array}{c}\text { Petroleum } \\
\text { Product }\end{array}$} & \multicolumn{3}{|c|}{ As on December 2015, \$1= BDT 80 } \\
\cline { 2 - 4 } Diesel & World & India & Bangladesh \\
& $\$ 0.79$ or & \$ 0.75 or & \$ 0.85 or \\
& BDT-63.20 & BDT 60.0 & BDT 68 \\
\hline Petrol & $\$ 1.01$ or & \$ 0.95 or & \$1.20 or \\
& BDT 80.80 & BDT 76.0 & BDT 96 \\
\hline
\end{tabular}

On the other hand, the selling price of the petrol is much higher than both World and India the difference is BDT 15.20 from World price and BDT 20 from that of India. This table is showing the profit margin and the present financial gain by the Bangladesh Petroleum Corporation. The next portion will be highlighted the loss and profit statement of BPC over the 10 year periods.
Table 7: Statement of Profit/(Loss) and Contribution to National Exchequer

\begin{tabular}{|c|c|c|}
\hline Year & $\begin{array}{c}\text { Loss by BPC } \\
\text { (BDT in Crore) }\end{array}$ & $\begin{array}{c}\text { Contribution to } \\
\text { National Exchequer }\end{array}$ \\
\hline $2003-2004$ & $(780.16)$ & 3033.00 \\
\hline $2004-2005$ & $(7.61)$ & 2766.00 \\
\hline $2005-2006$ & $(958.93)$ & 3087.27 \\
\hline $2006-2007$ & $(2317.88)$ & 2458.95 \\
\hline $2007-2008$ & $(3337.78)$ & 2620.26 \\
\hline $2008-2009$ & $(2314.63)$ & 2756.55 \\
\hline $2009-2010$ & $(7050.30)$ & 3003.61 \\
\hline $2010-2011$ & $(1022.63)$ & 1908.99 \\
\hline $2011-2012$ & $(2571.22)$ & 2324.25 \\
\hline $2012-2013$ & $(9799.91)$ & 3508.50 \\
\hline $2013-2014$ & $(11789.59)$ & 4659.77 \\
\hline $2014-2015$ & $(5368.70)$ & 4794.42 \\
\hline $2015-2016$ & $(2477.73)$ & 4854.06 \\
\hline $2016-2017$ & 5268.08 & 5448.61 \\
\hline Mean & $(3180.64)$ & 3373.16 \\
\hline
\end{tabular}

Source: Bangladesh Petroleum Corporation

The profit and loss account during the 2003 to 2017 where almost every year Bangladesh Petroleum Corporation has been experienced losses. But in the year of 2016 to 2017 till June the corporation gained profit of the amount of Tk. $5,268.08$ crore. Particularly, the profit margin is Tk 13.77 per liter for kerosene, Tk 14.68 for diesel, Tk 19.57 for furnace oil and Tk 18.75 for jet fuel. Moreover, the production cost of octane is Tk 56.85 per liter but the customers are buying it for Tk 99, giving the state-run corporation a profit of Tk 35.49 per liter. In the table 5 also shows the contribution of Bangladesh Petroleum Corporation towards National Exchequer.

Graph 2: The Elasticity of Gdp to Oil Prices Varies Widely Across South Asian Countries

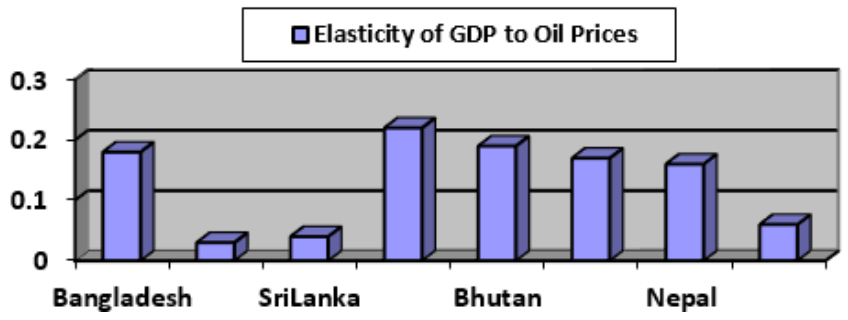

Source: World Bank Staff Calculations Based on World Bank, IMF and National Authorities Data

Graph 3: The Elasticity of Cpi to Oil Prices Varies Widely Across South Asian Countries

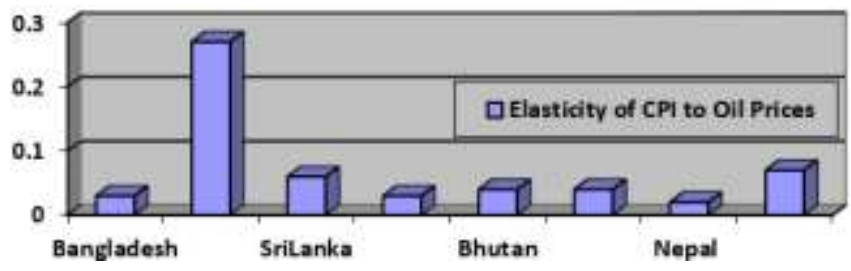

Source: World Bank Staff Calculations Based on World Bank, IMF and National Authorities Data 
Graphs $2 \& 3$ are showing the elasticity of GDP (Gross Domestic Product) and CPI (Consumer Price Index) to the Oil Price of the countries of south Asian region. The variation of the both graphs shows the relationships of oil price with GDP \& CPI of Bangladesh in comparing with other showed countries where Bangladesh is in the weak position in the very recent time especially in 2017 because BPC is doing more profit than the cost of the oil. Ultimately the public has to pay more price than the world and the south Asian countries.

The economy of Bangladesh is expected to benefit from the dramatic fall in oil prices that continued to zoom out. The consequent consumer benefit depends on the price adjustment at the domestic market commensurate with the international price. Lower oil expenditures helps decrease the cost of living via low transport expenses and bringing down inflation. Lower oil costs additionally pass by through at once into decrease gas prices and retail electrical energy prices.

Though the world oil price have been fallen and government of Bangladesh is imported the oil at decreased rate but the government is not willing to reduce the selling price of the oil because at past BPC has to spend Tk12, 000 crore per year as subsidy for the purpose of oil. To be mentionable here that BPC is making profit margin Tk 13.77 per liter for kerosene, Tk 14.68 for diesel, Tk 19.57 for furnace oil and Tk 18.75 for jet fuel. Moreover, the production cost of octane is Tk 56.85 per liter but the customers are buying it for Tk 99, giving the state-run corporation a profit of Tk 35.49 per liter. In view of the fact that worldwide fuel prices started to fall in mid-2016, domestic fuel prices have not been adjusted. Fuel subsidies have effectively turned negative, and the authorities have not indicated any plans to adjust them in the near term. In this respect the impact of the reduced oil price to the economy of Bangladesh might be as;

The oil exporting countries are suffering economic and political turbulence from the sharp fall of oil price. However, Bangladesh is standing in the green zone and getting the benefits from falling oil price as an imported. However, the retail consumers and business enterprises of Bangladesh have not benefited despite of the falling oil price. Lower oil costs if preserve ought to have a nice impact on domestic growth. In theory, the fall in oil expenditures may lead to greater purchasing electricity and hence add to actual GDP.

The effect of decrease oil expenses is broadly high- quality to oil importers like Bangladesh. The authorities have to spend billions of dollars as oil import consignment every year. The fall in oil prices, therefore, convert into massive overseas trade savings. They have an effect on of the falling oil prices has contributed in saving foreign currencies as reflected in the LC opening figures. The price of LC opening fell about $20 \%$ in the July-October period of 2015 as compared to the identical period last year.
Lower oil expenses will minimize transport costs, production costs and mills expenses (diesel is a predominant supply of electricity used in rice farming). Though in June 2014 inflation price got here down to decrease than 6 percent, the ordinary inflation at some point of FY2014 went up to $7.5 \%$ in opposition to a target of 7\% in the Monetary Policy Statement (MPS) of Bangladesh Bank announced in January 2014. High food inflation led to a greater inflation. This was by and large due to disruption of mills supply at some point of the length of political turmoil. The MPS of June 2014 set $6.5 \%$ as the target inflation price in FY2015. In October 2015, factor to factor inflation came down to $6.6 \%$ and average inflation also got here down to 7.18 percent, primarily driven by means of low non-food inflation. Though domestic production, in particular that of rice influences output and price stability, inflation in Bangladesh is also generally determined via worldwide expenses in view that the United States has to rely on a range of fundamental commodities together with petroleum products. Hence lower expenses of food and oil at the worldwide market at existing has been a distinguished component for low inflation rate.

Low petroleum fees also help domestic inflation to be low seeing that a huge amount is spent on petroleum merchandise by buyers in Bangladesh. A depressed gasoline charge additionally affords leverage for the government to hold home fuel expenditures low which in turn will provide some respite to consumers, specifically the low and constant earnings companies who can then spend their financial savings for other purposes. Bangladesh depends on RMG exports and remittances through temporary migrants abroad for high foreign exchange reserves. If oil rich countries plan to cut down their apparel imports and reduce employing foreign labor, it will seriously harm international locations such as Bangladesh. Thus the country will need to be cautious and techniques its function to face any such sputtering situation. Maintaining macroeconomic stability, increasing effectively in undertaking implementation, mainly that of the infrastructure and improving governance is some of these challenges.

While the upcoming year will may not see many changes in case of these challenges, the financial system is expected to exhibit a glimmer of hope in terms of greater GDP increase given the relative financial and political stability. However, achievement of the focused growth of 7.3 percentages as spelt out in the budget of FY2015 will require lively efforts for boosting funding through gaining enterprise self-belief and improved commitments towards reforms, amongst others.

\section{CONCLUSION}

This present study may help the consumers and the policy makers to know the comparative analysis on oil price both in the world and Bangladesh and its present \& potential impact over the country's economy. Despite political 
turmoil, structural constraints, and international volatility, the Bangladeshi financial system is maintaining macroeconomic stability and moving forward.

The global recovery, robust home demand growth, and sustained macro steadiness bode properly for Bangladesh's GDP boom and poverty reduction and Bangladesh comfortably reached middle income status. Bangladesh was also able to contain inflation due to favorable international commodity price movements and sound macroeconomic management. The economy is getting the benefits of the falling expenses of oil as the government's spending on subsidy will go down substantially and stability of payments will be healthier. The price of fuel oil has come down to a half in the last one year but the government is selling the oil at the old price. The price of the fuel oil is now third highest in Bangladesh around the world. Energy analysts found two fold reasons for the sharp fall of world oil price such as weak demand in many countries due to insipid economic growth, and shale oil production surging US production. While Bangladesh is in the process of rationalizing oil expenses via phasing out subsidies and hiking its expenditures commensurate with the global price, a subdued world petroleum market would mean lesser subsidy requirement. Savings from decrease subsidies ought to otherwise be used for infrastructure development and social protection. A depressed gasoline fee also provides leverage for the authorities to maintain domestic gas prices low which in flip will give some respite to consumers, specifically the low and constant earnings businesses who can then spend their financial savings for other purposes. Low petroleum expenses additionally help domestic inflation to be low considering the fact that a considerable amount is spent on petroleum merchandise by means of consumers in Bangladesh. The steady fall in the international market for over a year has made it clear that oil prices in Bangladesh will drop after adjustment. Besides, the government is saving money from its budget. In the last 2014-15 fiscal, the subsidy to the sector amounted to a total of Tk 2,400 crore. But the expenditure was only Tk 700 crore as subsidy, suggesting that the government is making profit from all sides thanks to the fall of oil price in the international market whereas the consumers cannot save a single penny.

\section{REFERENCES}

ADB (2015). Scaling up to Meet New Development Challenges, Asian Development Bank, 2015, Retrieved from https:/ /www.adb.org/sites/default/files/institutionaldocument/182852/adb-annual-report-2015.

Awale, Y., Namusonge, G., \& Warren, K. (2016). Implementation of Strategic Plans on Oil Distributors: A Study on Selected Oil Companies in Kenya. American Journal of Trade and Policy, 3(1), 37 - 44.

Baqutayan, S., Abdul Shatar, S., Md. Salimun, H., \& Abu Hassan, N. (2016). Towards the Sustainable Development by 2020:
Malaysia Perspective on Economic Growth and Wellbeing. American Journal of Trade and Policy, 3(2), 87-92.

Haque, A. K. E. (2007). Impact of World Oil Price Rise on the Economy of Bangladesh, REP, UNDP, Bangkok and Economic Research Group, Dhaka

Kardel, M. (2016). Irans Oil and Gas Legal Framework: from Exploration to Revolution. Asia Pacific Journal of Energy and Environment, 3(2), 51-58.

Masami, K., (2013). "Petroleum product pricing and complementary policies: Experience of 65 developing countries since 2009." Washington DC: World Bank.

Ogunyomi, O., Daisi, O., \& Oluwashikemi, R. (2013). Economic Globalization, Income Inequality and Economic Growth in Nigeria: A Static Data Analysis (1986-2010). ABC Journal of Advanced Research, 2(2), 130-143.

Rahman, M. (2015). State of the Bangladesh Economy in FY2015 and the Closure of Sixth Five Year Plan, Centre for Policy Dialogue (CPD), IRBD

Rahman, S. (2014). Credit goes to oil price decline on global markets, The Daily Star, on Friday, 12 December

Tabassum, T., (2015). How falling international oil prices are affecting Bangladesh, Light Castle Analytics Wingin.

Tamim, M. (2015). Energy pricing dilemma and the culture of subsidy, The Daily Star, March 12, 2015, Retrieved from https://www.thedailystar.net/supplements/24thanniversary-the-daily-star-part-3/energy-pricing-dilemmaand-the-culture-subsidy

Taslim, M. (2014). Asymmetric Transmission of International Price of Edible Oil in Bangladesh, XXXVIII(1).

\section{Websites}

http:/ /www.bbc.com/news/business-29643612

http://www.dhakatribune.com/business/economy/2014/12/ 04/falling-oil-price-a-boon-for-bangladesh/

http://www.worldbank.org/en/news/pressrelease/2015/04/13/south-asia-cheap-oil-reform-energypricing

https://thefinancialexpress.com.bd/views/proposal-for-oilprice-hike-raises-concern

https:/ / www.economicshelp.org/blog/11738/oil/impact-offalling-oil-prices /

https: / www.slideshare.net/JakirHossainRubal/the-causes-offalling-the-oil-price-and-effects-in-bangladesh

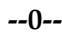


Online Archive: https://abc.us.org/ojs/index.php/abr/issue/archive 